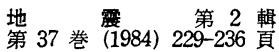

\title{
群速度を用いた震央波形の推定
}

\author{
気象大学校 松森敏幸* ・古屋逸夫 \\ (昭和 59 年 1 月 26 日受理)
}

\section{Application of Group Velocity Method to Reducing Dispersed \\ Wave Trains to Original Pulse Forms}

\author{
Toshiyuki Matsumori and Itsuo Furuya \\ Meteorological College, Japan Meteorological Agency
}

(Received January 26, 1984)

\begin{abstract}
An attempt is made to restore the original pulse forms from dispersed wave trains by using group velocity data in place of phase velocity data. For a given period, the group velocity is obtained, eventually, by usual method to interpolate group velocities of adjacent peaks of dispersed train, but the validity of the method is interpreted in slightly different way from the usual one.

Calculations are made for fictious dipersed train whose original form is known and for actually recorded data whose original form is unknown. The estimated pulse is of a form not completely free from uncertainties, but may be utilized to check an assumed source mechanism.
\end{abstract}

\section{§1.まえがき}

地下構造の違いによって表面波の分散が異なることを利用して地下構造を推定することは表 面波の第一番目の利用法であり，多数の研究者によって多数の論文が出版されている．また， 表面波を利用して発震機構を推定することは表面波の利用法のもう一つの重要な部分である. 普通行われる利用の仕方は，震源パラメーターおよび地下構造を仮定した上で，波形を含めた 理論と観測との比較を行い，仮定された震源パラメータの妥当性を判断することである[例え ば, BEN-MENAHEM (1961), KANAMORI (1970 a,b)].

この論文では，震源パラメータを決定するという最終目的の一つを追求するのでなく，その 目的の一助になる震源めるいは震央附近の “波形”を簡単に推定することを試みる. 震源拉上 び震央附近で波形がどういら形をしているかは，発震機構の研究にとつて重要な情報であろう。 分散した表面波データから，直接距離ゼロの所の波形を求める方法は，(i) 記録をフーリエ变 換して，位相補正をした後に，逆変換をして求める方法 [SATO $(1955,1956)]$ ， (ii) 震央々観 測点の間の媒質を一種のフィルタとみなし，そのインパルス応答と記録との相互相関をとる方 法 [AKI (1960)] がある.どちらの場合にも震源と観測点との間の位相速度 Cを知ることが

昭和 57 年 4 月 10 日発表

* 現所属松江地方気象台西郷測候所 
不可久である.

位相速度 $C$ の計算は, 理論的には地下構造を与えて簡単に計算できる. しかし, 実際の記 録から C を求めることは，BRUNE et al. (1960) は巧妙な方法を提案したが，それとてそれ 程簡単なことではない，それに反して，群速度 $U$ は一観測点の記録から容易に求めることが できる.SATO (1955) は位相の不確定性を考慮して何本かの位相速度曲線を書き，それから通 常の方法で群速度を求め, それと測定された群速度との比較によつて正しい位相速度曲線を求 める方法を示し，実地に適用もしている，また，群速度を積分して位相速度を求める方法も， 不確定要素はあるにせよ，何かの役に立つはずであるがそれを利用して位相速度を求めた例は 多くなく，使い方によっては有用であるはずであるとも述べている [SATO (1978)].

以下では，震央波形（距離ゼ口の波形をこう呼ぶことにする）について，簡単に記録から求 まる群速度 $U$ を直接用いて何が分るかを検討する.

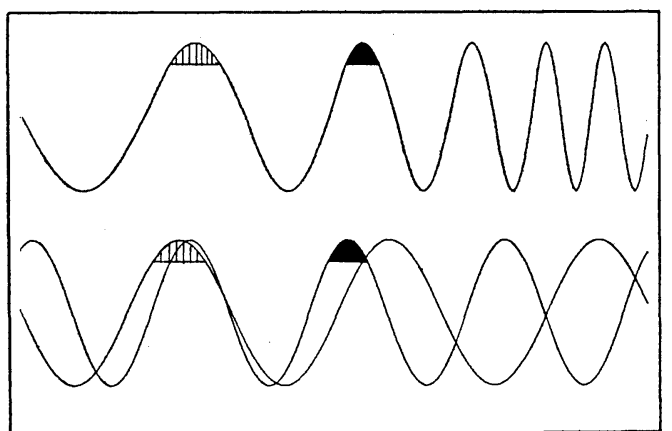

Fig. 1. Dispersed wave train and its two component waves whose periods correspond to two adjacent peaks of dipersed wave train. Corresponding peaks lie at an approximately same position.

\section{§2. 方法}

震央距離 $x$ で観測された波形は, 伝播に上る位相の遅れ $\omega x / C$ を補正す ることによって，震央波形に戻すこと ができる.

$$
\begin{aligned}
f(t)= & 1 / 2 \pi \cdot \int_{-\infty}^{+\infty} X(\omega) \\
& \times \exp \{i(\omega t+\omega x / C)\} d \omega .
\end{aligned}
$$

ここで， $X(\omega)$ は観測波形のフーリェ 変換である. BRUNE et al. (1960) に よれば分散波形の各々のピークは，そ れぞれの角振動数 $\omega$ に等しい成分波

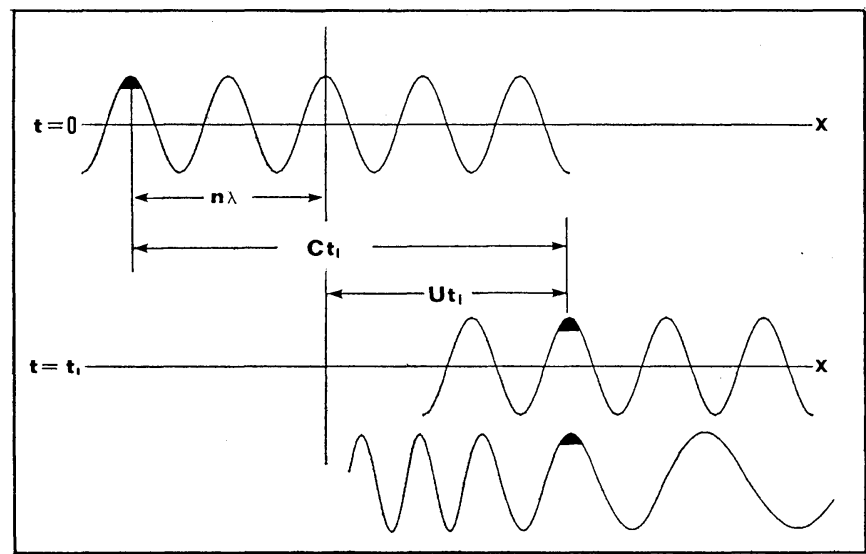

Fig. 2. Travelling of component wave whose velocity is C. One of its peaks corresponds to the peak of dispersed wave with the same period. The original figure of Brune et al. (1960) is slightly modified here. 
の一つのピークに対応している (Fig. 1). 時刻ゼロのときのそのピークが震央の向う側 $n$ (一 般に実数）波長のところにあつたとすると，Fig. 2 より

$$
C(\omega) t(\omega)-x=n \lambda(\omega)
$$

が成り立つ. ここで, $C(\omega, t(\omega), \lambda(\omega)$ はそれぞれ角振動数 $\omega$ の位相速度, ピークの到達時刻 及び波長である. 一方, 群速度 $U(\omega)$ は

$$
U(\omega)=\frac{x}{t(\omega)}
$$

であるから， $\omega=2 \pi C / \lambda$ を使うと

$$
\frac{\omega x}{C(\omega)}=\frac{\omega x}{U(\omega)}-2 \pi n
$$

が求まる. (3) は角振動数 $\omega$ の位相を距離ゼロにもどすための位相補正である.

（3）式は, 今までのところ, 角振動数 $\omega$ に対応するピークの位相補正であることに注意し なければならない（1）式の計算には，必要とする帯域のすべての振動数に対する位相補正が 必要である. 考えている帯域で位相速 度がゆるやかに変化し，また初期位相 も注ぼ同じだとすると，分散波形中の となり合つたピークの番号 $n$ は 1 だ け違うと考㝋て良い [Fig. 1，および BRUNE et al. (1960)]. ところで, 考 えている帯域で分散が単調（正常分散 あるいは，逆分散）だとすると到達時 刻とそれに対応する振動数は 1 対 1 に 対応している，例えば，となり合つた ピークの周期が 50 秒，40 秒の成分 波のピークに対応し，かつその中間の 「斜面」はそれぞれ，49 秒，48 秒, ……，の成分波の対応する「斜面」に 対応している. したがつて，50 秒の ピークに番号 $n$ を与光ると，40 秒の ピークは $(n+1)$ の番号を持つており, その中間の 49 秒, 48 秒, …..., 等は $n$ と $(n+1)$ の中間の值を持つことに なる。

以上は正常分散の場合であるが，逆 分散の場合も全く同様である. 帯域中 にエアリー相を含む場合にも，記録に ハイカットあるいは，ローカットのフ ィルターを掛け，正逆の部分について，

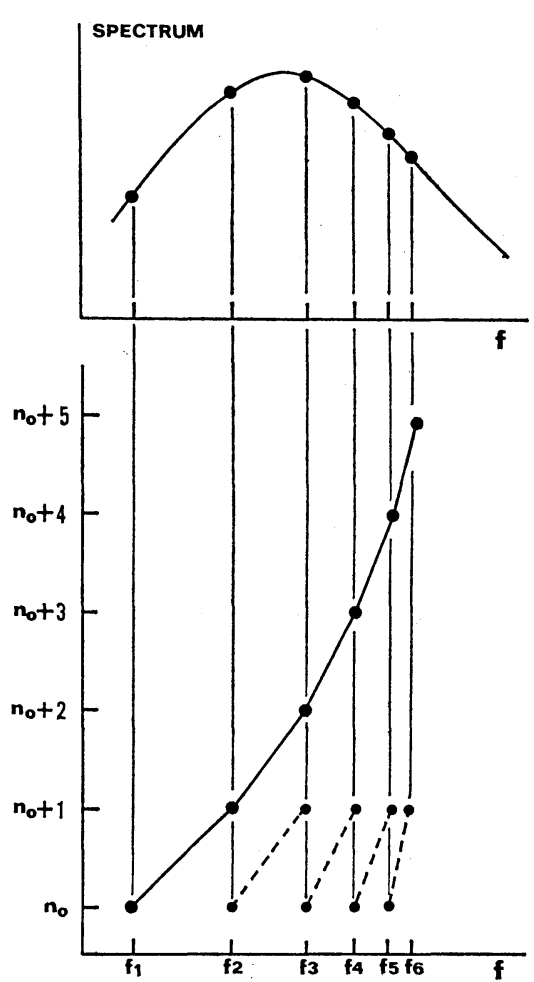

Fig. 3. Schematic diagram to determine the phases of peaks and their intermediate slopes. Solid circles correspond to the peaks of dispersed wave train. The phase expressed by solid line can be replaced by dotted lines. 
それぞれ同様に考えることができる。

このようにして，あるピークの番号 $n$ を決めれば分散波形の任意の位置の番号が決まり， （3）式は考えている帯域の任意の $\omega$ について決めることができる. (3) 式は位相補正である から $n$ が整数だけ違つても（1）式の計算に影響しない。また，0.5 違うと（1）式は符号が 反転するだけである.したがつて， $n$ については 0 ～ 0.5 の不確定要素が残ることになる. $n$ が連続的に 0 から 0.5 まで変化するとき，(1) 式の波形も連続的に変化し，どれが正しい震 央波形かを決めることはできない。それでもなお結果には役に立つ情報が含まれているはずで ある.

\section{§3. 計 算 例}

前節に記した各ピークとその中間の振動数に対応する $n$ の関係を Fig. 3 に示す. 上図は 波形のスペクトルであり，黒点は各ピークに対応する.ここでは，正常分散の場合が描かれて おり，横軸の振動数 $f$ は，同スケールではないが波の到達時刻に対応していると考えて良い。

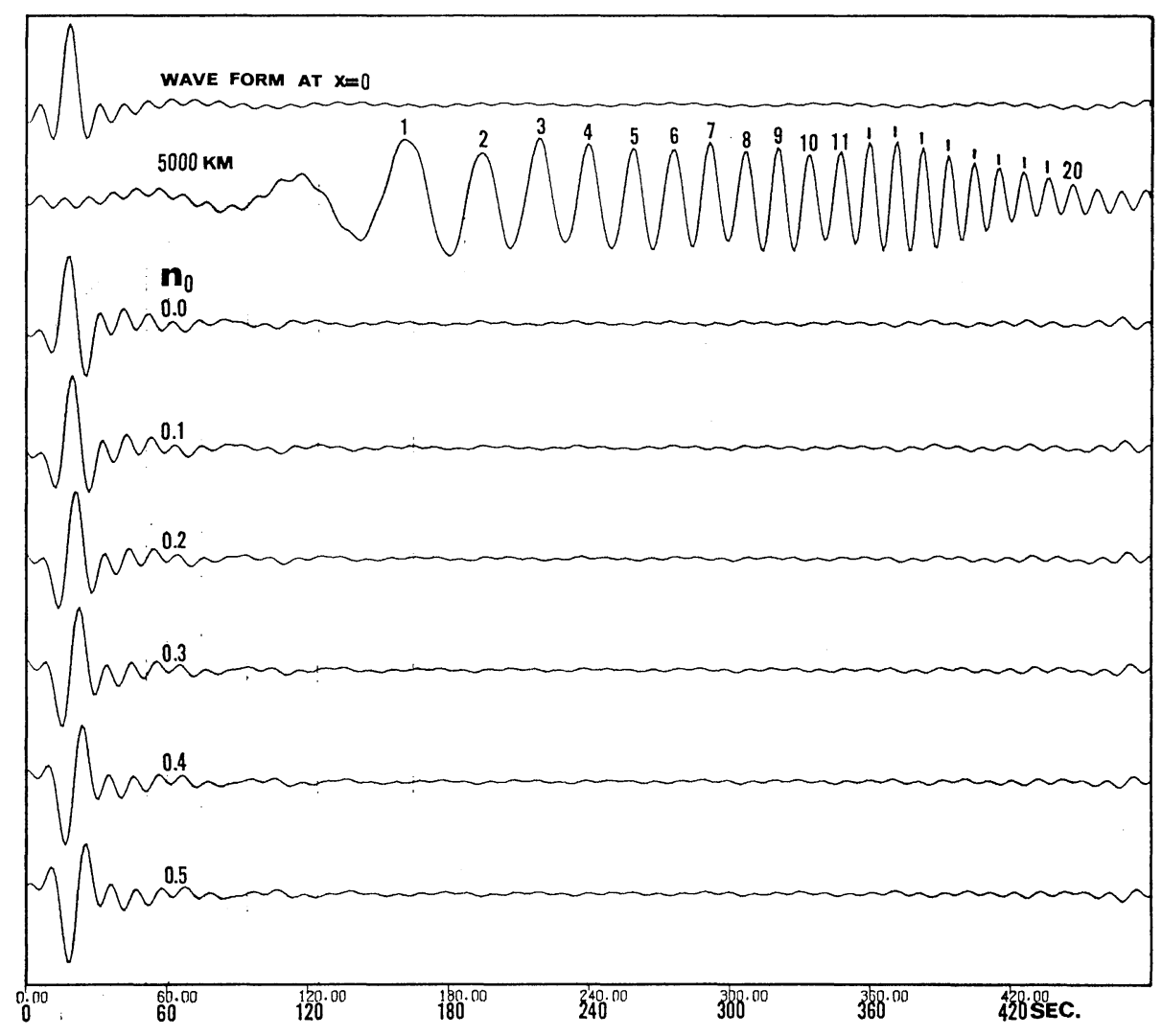

Fig. 4. The result of calculations. The original wave form (upper trace) advances with the velocity $C(T)=-6 / T+4.6$ and the dispersed wave train at $\Delta=5000 \mathrm{~km}$ is obtained (2-nd trace). Using this wave form as original data, calculations are made for $n_{0}=0.0 \sim 0.5$. Group velocities are determined for the first 20 peaks which are numbered in the figure. 
各ピークの中間の振動数の $n$ は，ここでは各ピークのそれを直線で結んだものを使う． $f$ が 大きくなるにつれて, $n$ も大きくなるのであるが, 整数だけ違つても同じ結果が得られるはず だから，図中の点線で表わされる $n$ を使つてもかまわない.

まず, 震央波形は Fig. 4 の一番上の形をしているものとする.ここに含まれている振動周 期は約 10 秒から 60 秒である.この震央波形を適当な位相速度（ここでは，特に意味はない が， $C(T)=-6 / T+4.6)$ で分散させたときの $\Delta=5000 \mathrm{~km}$ における波形がその下に示されて いる.これを記録波形として 2 章の方法を適用する.ピーク 1 の $n$ を $n_{0}$ とすると，ピーク 2 の $n$ は $n_{0}+1$, ピーク 3 の $n$ は $n_{0}+2$ 等となる. $n_{0}$ は 0 と 0.5 の間の值を与えれば十 分である. 各ピークの周期をそれをはさむ谷の間隔として群速度を求める. Fig. 4 ではピーク を 20 個をで読んだ. ピーク 1 の周期は約 38 秒と読みとれたので，記録に実際に含まれる 38〜60 秒の部分は計算から除外しなくてはならない.

$n_{0}=0,0.1,0.2,0.3,0.4,0.5$ に対応する計算結果を Fig. 4 の下部に示す. $n_{0}=0$ と $n_{0}=$ 0.5 の場合は単に符号をとりかえただけの形になつている. $n_{0}=0.1$ ぐらいのときが最も良く 最初の震央波形に合つているが，もちろん，データだけからはどれが合つているのかは分らな

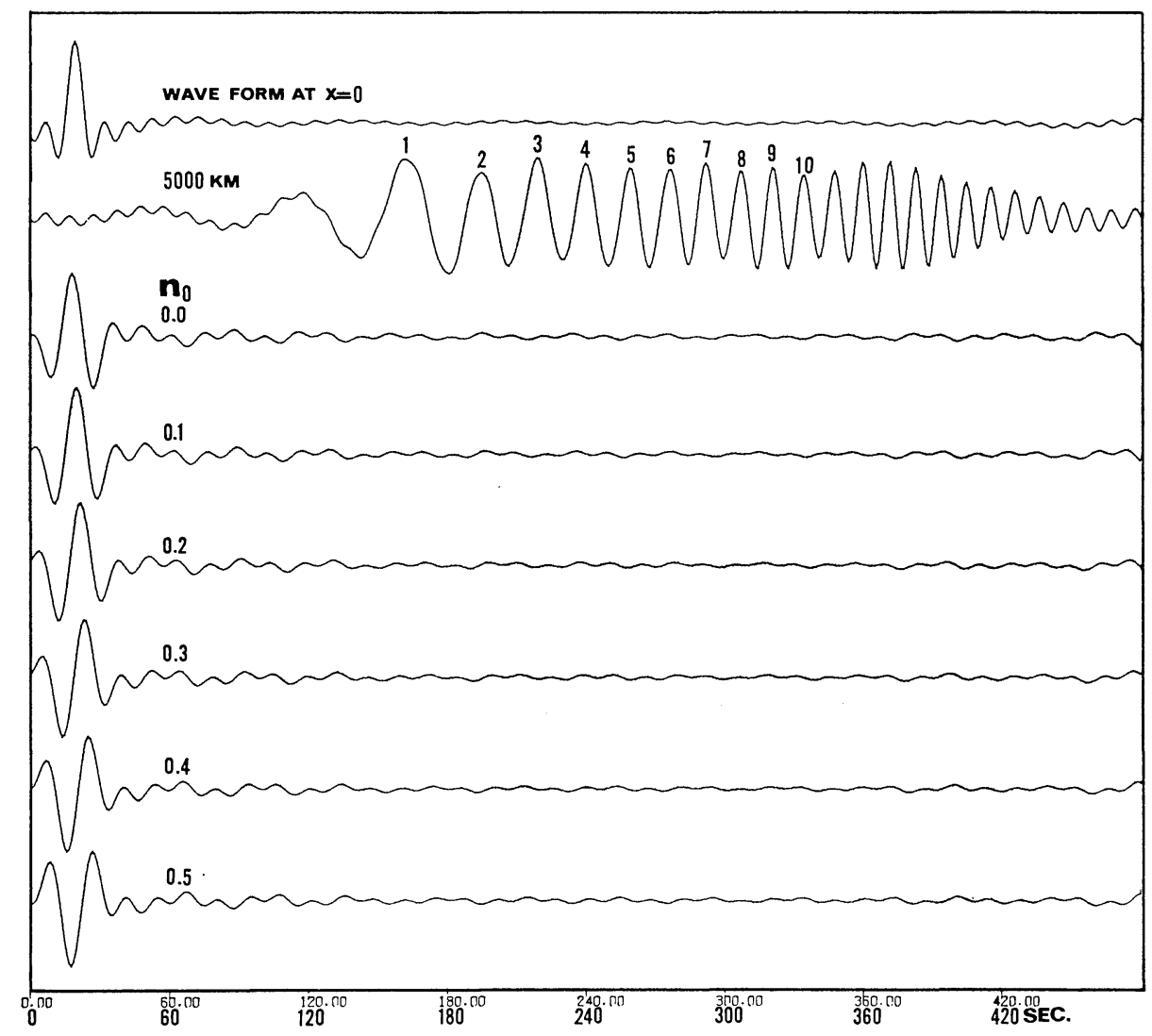

Fig. 5. The same result as Fig. 4 except that group velocities are determined only for the first 10 peaks. 


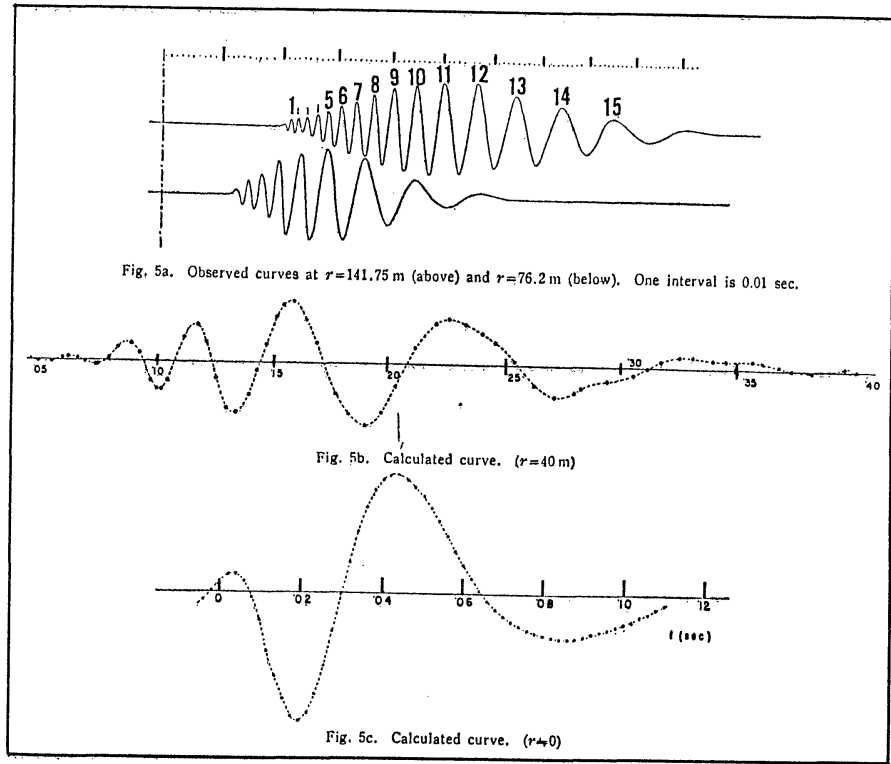

Fig. 6. Reproduced from Fig. 5 of SATo (1955). Uppermost figure is actual record obtained by explosion experiments on the ice-covered Harunako Lake. Intervals between time tick marks are 0.1 seconds (originally the points with 0.01 second intervals are plotted). Lowermost figure is the wave form at $r=0$ calculated by SATo. Intervals between time tick marks are 0.02 seconds.

W.

Fig. 5 も読みとつたピークの数を除いて, Fig. 4 と全く同じものである. 読みとつたピー クの数は 10 個であり, 10 番目のピークの周期は約 13 秒なので, Fig. 5 の場合より短周期 の部分が計算からさらに除外されている. 結果は, 当然のこととして短周期がわずかげかり欠 けたよらな形にはなるが，本質的には前図と变りはない。

次の例としては，実際のデータを使つてみる．Fig. 6 は SATO の論文 $(1955,1956)$ に出 ているもので，榛名湖の氷の上での爆破記録である．きれいな逆分散を示している．Fig. 6 の 下の部分は位相速度を用いて SATO が計算した爆破点付近の波形である. $r=141.75 \mathrm{~m}$ の記 録に 2 章の方法を適用した結果を Fig. 7 に示す. 図にはSATO の結果を点線で原点をずらし て重ね書きしてある. $n_{0}=0.1$ あるいは 0.2 ぐらいのときの計算結果とよく似ている．ただ し, 震源時で約 0.03 秒の違いがある.この違いが無視できる違いか本質的な違いかは検討を 要するところであるが今のところ計算方法の違い及び読みとり誤差の違いといら理由の他に適 当な理由つけけはできない。

\section{$\S 4$. 検 討}

となりあつたピークに対応する周期の群速度からその中間の周期の群速度を上のよらな考え で求める，ということは結局, 記録のピークの周期を読みとつてその分散曲線上の点をスムー ズにつなぐ，といら通常の仕方と全く同じことである．この論文では，その点と点を曲線（こ こでは直線であるが) でスムーズにつなげる，ということがどういう意味を持つているのかを 


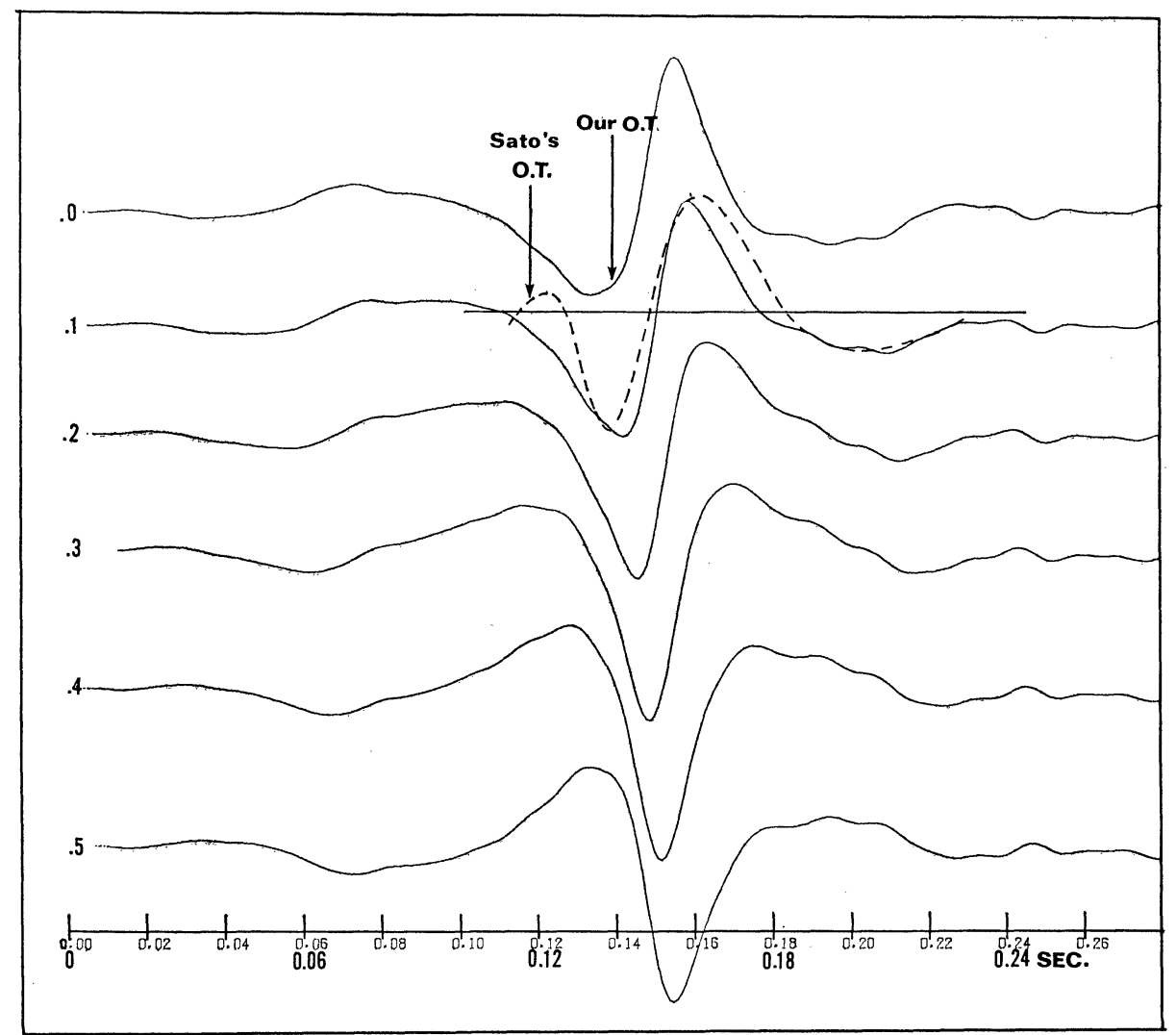

Fig. 7. The result for five $n_{0}$ 's by applying our method to the record at $r=141.75 \mathrm{~m}$ in Fig. 6. SAT0's result (lowest trace in Fig. 6) is overlapped in the figure. Arrows point to calculated origin times. Their positions are different by 0.03 seconds.

理由づけている，という意義があるだけかも知れない。

しかし，群速度のみを用いて計算された結果をみると，いくつかの有用な結論が得られるよ らにみえる.

まず，実際の震央波形がパルス状とみなせるような場合には，Fig. 4〜7 7 みて分るよう に， $n_{0}$ をいくつにしてもすべてパルス状にみえ，これは波形の継絸時間のみがほしいときに は，位相速度が分らなくても群速度を使つてある程度の類推ができることを示している．波形 の継続時間は震源の継続時間と関係があるだろらから, 震源パラメータの推定に寄与できるだ ろう。

次に，Fig. 4〜7 は最大值を同じ幅にして描かれているが，実際の最大振幅も絶対值として 同じ程度の值を持つている. これは波の放射パターンを求めるときに，位相速度でなくても群 速度をつかつて十分実用的であろうことを示している．表面波の放射パターンもまた震源パラ メータのチェックに役に立つものと思われる.

また，十分に分散した表面波形の記録があるとして，すべてのピークに対応する群速度が読 めたとしたらそれに越したことはないが，先頭のいくつかのピークからのデータのみでもある 
程度の結果が得られることも示したものと思う。

以上の計算では，分散波形のピークとそれに対応する成分波のズレ，及び二次元的な拡がり による位相のズレ [BRUNE et al. (1960)] は考慮に入れなかつた。それが，Fig. 7 における 震源時間の 0.03 秒のズレに影響しているかも知れない。そのような考慮は式を少しばかり複 雑にするだけであるが，上の本質的な部分には大きな影響を与えないだろう。

\section{文献}

AkI K., 1960, Study of Earthquake Mechanism by a Method of Phase Equalization Applied to Rayleigh and Lovd Waves, J. Geophys. Res., 65, 729-740.

Ben-Menahem A., Radiation of Seismic Surface Waves from Finite Moving Sources, Bull. Seism. Soc. Amer., 51, 401-435.

BRune J. N., J.E. NAFE and J.E. Oliver, 1960, A Simplified Method for the Analysis and Synthesis of Dispersed Wave Trains, J. Geophys. Res., 65, 287-304.

KANAMORI H., 1970a, Synthesis of Seismic Surface Waves and Its Application to Earthquake Source Studies-Kurile Islands Earthquake of October 13, 1963, J. Geophys. Res., 75, 5011-5027.

KANAMORI H., 1970b, The Alaska Earthquake of 1964: Radiation of Long Period Surface Waves and Source Mechanism, J. Geophys, Res., 75, 5029-5040.

Sato Y., 1955, Analysis of Dispersed Surface Waves by Means of Fourier Transfrom I, Bull. Earthq. Res. Inst., 33, 33-48.

Sato Y., 1956, Analysis of Dispersed Surface Waves by Means of Fourier Transform II. Synthesis of the Movement near the Origin, Bull. Earthq. Res. Inst., 34, 9-18.

佐藤泰夫，1978，地震波動論，岩波書店，239-242。 